\title{
Europe and Japan
}

\author{
Shogo Suzuki ${ }^{1}$ \\ ${ }^{1}$ Department of Politics, University of Manchester, Manchester, UK \\ Correspondence: Shogo Suzuki, Department of Politics, University of Manchester, Oxford Road, Manchester \\ M13 9PL, UK. Tel: 44-161-275-0906. E-mail: shogo.suzuki@manchester.ac.uk
}

Received: November 24, 2011 Accepted: April 26, 2012 Online Published: July 1, 2012

doi: $10.5539 /$ res.v4n3p54

URL: http://dx.doi.org/10.5539/res.v4n3p54

\begin{abstract}
This article traces the historical evolution of the images of Europe in Japan. While the length of Japan's interactions with Europe do not compare to those between China, Korea, and Japan, the Europeans have nevertheless played a significant role in the process of constructing a Japanese identity. While Europe initially played a part in consolidating ethnocentric notions of Japanese superiority, since the expansion of European International Society in the late-nineteenth century, Europe has played a role as a "positive" other that Japan has frequently sought to emulate and mimic, even at the height of Japan's rebellion during the Asia-Pacific War of 1931-1945. This dynamic has persisted to this day, even under the shadow of American hegemony and Japan's incorporation into this order after 1945.
\end{abstract}

Keywords: Japan, Europe, self, other, identity, hybridity, history, image

\section{Introduction}

At first glance, Japanese perspectives on Europe may seem somewhat out of place in a volume which explores whether or not post-colonial perspectives would provide a useful methodological lens to reinterpret the European Union (EU). Unlike many other countries in the non-European world, Japan did not experience outright colonization at the hands of the European powers during the height of Europe's expansion in the late-nineteenth century. The task becomes even more difficult when we turn our focus to the emergence of the EU as a new political actor in its own right. As has been documented in detail elsewhere, the international order since the end of World War II (WWII) has commonly been described as one characterized by American hegemony (Ikenberry, 2000), and as the United States (US) is both an Atlantic and Pacific power, it is not particularly surprising that Japan's gaze has tended to be fixed more on the US rather than the EU. Japan has been integrated into the American-led regional and international order. Its pillar of security policy remains the US-Japan security alliance, where Japan maintains a defense-oriented military force under the constitutional limits of Article 9 and relies on the US to provide it with additional military support.

The EU, for its part, is not a particularly large player in the Asia-Pacific, despite its involvement in a number of diplomatic dialogues such as the China-EU summits or the ASEAN-EU Ministerial meetings. Its involvement in East Asian regional political affairs remains minimal, given the presence of Japan, China, and the US. Japan's interactions with the EU are seen as primarily of an economic nature, with much analysis on Tokyo and Brussels' ongoing trade disputes. Bretherton and Volger note that the "EU-Japan relationship has remained almost exclusively trade focused. Up until the early 1990s there were few formal links.... and it was significant that the head of the EC delegation in Tokyo was not granted the usual full ambassadorial status and accreditation to the Emperor" (Bretherton and Volger, 1999: 69). When it comes to political relations, we are informed that both sides have found it in their interest to deepen their ties, given that this "might create a more benign environment for finding solutions to the rising economic frictions and inequities" and also because "Japan discovered that gaining support from the EU as a whole for certain political issues could enhance its international position, particularly on issues which it does not see eye to eye with the United States" (Drifte, 2000: 202). The otherwise stable political relations mean that there is very little to report.

Historically, however, this was not always the case. As we will see below, the Europeans have played a surprisingly important part in the construction of Japanese identity - and Japanese views of Europe fluctuated in 
accordance with their evolving perceptions of the Japanese "Self". The aim of this article, then, is to provide a broad historical overview of the evolution of Europe's role in the construction of Japan's identity. It does this by utilizing the "Self" and "Other" framework of identity formation, which, put simply, assumes that the construction of an identity requires the construction of an "Other" whose differences from the "Self" are emphasized. The essay proceeds as follows. In the following section, I suggest that Europe has played a surprisingly more prominent part as an "Other" in shaping Japan's identity (Note1) by examining Japanese and European interactions under the East Asian international order. Having argued that Europe played a role in confirming Japanese notions of superiority, I then turn to the late-nineteenth century, where Europeans now forced the Japanese to accept the "standard of civilization" and notions of non-European inferiority. Japan's forced entry into the European-dominated international order was in some ways the beginning of the lingering influences of Europe as a "positive other" which Japan aspires to share the same identity with: the third section thus briefly examines Japan's attempts to "enter Europe" after World War II.

A number of qualifications should be made explicit from the outset. Firstly, while this is hardly the place to elaborate upon the various theoretical debates surrounding the vast literature of identity formation in International Relations (Neumann 1999; Rumelili, 2004; Abizadeh, 2005; Bukh, 2010: 1-15), it should be acknowledged that social actors living in complex societies will have multiple, often overlapping identities. This therefore means that there will be several "Others" who play a part in the construction of self-identity. Secondly, the "Self-Other" approach adopted here is sociological, and assumes that identity formation is an ongoing process which involves interaction between social actors. The implication of this is that the construction of "Others" is dynamic, and the importance a particular "Other" has can change over time. Naturally, it is impossible to capture this complex process in one article, and for this reason my enquiry is limited to a small section of this dynamic, and focuses on the role of only one actor, Europe. Furthermore, it is limited in its scope in that its primary empirical focus is on broadly on political elites, rather than the political opposition or civil society actors.

\section{Historical Views of Europe}

Japans' first contact with the Europeans (the Portuguese) took place in 1543, and was quickly followed by the arrival of the first missionaries in 1549. While trading relations (primarily with Portugal, Spain, Holland, and England) were quick to take off, once the Tokugawa shogunate (1603-1867) came to power it gradually began implementing the policy of sakoku between 1633-1641, where contact with Europe was ultimately restricted to the Netherlands alone, at the port city of Nagasaki. Japanese were forbidden to travel overseas, and Japan is commonly perceived to have "cut itself off" from the European world.

It is, however, more appropriate to think of European-Japanese relations as taking place under the constitutional structures of the East Asian international order, which had originated from China and were undergirded by Confucian ideology (Reus-Smit, 1999; Fairbank, 1968; Mancall 1984; Zhang 2001). As Yongjin Zhang (2001) has noted, in this social setting, interstate relations were conducted on a hierarchical basis, rather than sovereign equality: there was a 'centre' which stood at the apex of this order - usually China - and its ruler was assumed to be a mediator between humankind and heaven. The maintenance of these social hierarchies was seen as a crucial means of attaining social harmony and ultimately the happiness of the peoples of the respective member states of this international order. Diplomatic relations between states operated on the basis of "ritual justice", which meant that legitimate conduct was based on elaborate rituals and ceremonies which functioned to maintain and strengthen the given social hierarchy of the East Asian international order.

These constitutional structures found their institutional expression in the famous Tribute System. Under this arrangement, diplomatic missions consisted of foreign emissaries presenting "tribute" - gifts for the ruler of the state that occupied a higher place in the social hierarchy. As a reward for their fidelity and submission, the rulers of the lower-ranking polities were given "favors" such as investiture, trading rights, and gifts of higher value. These diplomatic interactions were highly ritualized and were designed to demonstrate that that the ruler of the host country had attained the moral authority as an "ethical ruler", to the extent that foreigners were presenting tribute and placing themselves below the ruler in the Confucian social hierarchy.

Japan's long-standing historical legacy of interactions with China and Korea (both key members of the East Asian international order) and cultural learning from the Chinese continent meant that the Japanese were deeply embedded in the social structures of this Confucian-influenced international social environment (Howell, 1998:119-120). This meant that many of their diplomatic institutions were broadly similar to those of other members of the East Asian international order. Crucially, this remained the case even when the policy of sakoku had been implemented. As Tanaka Takeo has noted, Japan's sakoku policy shows considerable similarity with the 
"seclusionist" policies (known as haijin in Chinese) adopted by Ming China and Korea (Tanaka, 1975: 85-86; Toby, 1991: 96) (Note 2). The policy eventually evolved to support the hierarchies of the East Asian international order and was adopted by China's neighbors. By limiting the available channels of contact, the East Asian rulers forced foreign merchants to participate in "official" trade and its rituals, where member states attempted to demonstrate and shore up their "superior", "civilized" status. The policy of sakoku therefore functioned to enforce a state's own vision of international relations on other polities (Arano, 1998: iv).

By the time of the Tokugawa shogunate, however, Japan was less willing to accept the Sino-centrism that is often seen as a hallmark of the East Asian international order. Instead, the Japanese placed Japan at the apex of civilization (Note 3). This process was hastened by the rise of the "barbarian" Manchurian Qing dynasty in China. The Tokugawa shogunate refused to send any tribute missions to China and admit to the latter's "superiority". Instead, the Japanese began to invite their own neighbors to send tribute to Japan instead. These diplomatic policies were hardly "isolationist": rather, as Toby (1991: 96) argues, they “...should be seen as part of a much larger foreign policy embracing all of Japan's world. That foreign policy made tradeoffs...The Tokugawa tradeoff was between unrestricted foreign commerce, on the one hand, and the demands of sovereignty, security, and legitimacy, on the other."

In order to reinforce the notion that the Tokugawa clan had unified Japan and were the rightful rulers of the land, the first shoggun Tokugawa Ieyasu appealed to the Confucian notion of ideal government that he had "unified the country... rectified administration and brought prosperity to the people; and his dynasty had already attained its third generation" (Toby, 1991: 60). Korean and Ryūkyū (present day Okinawa) rulers were encouraged to send missions in order to demonstrate that the shogun's prestige had spread far and wide. As one Japanese feudal lord put it in the context of the Korean mission's visit to first Tokugawa shogun Ieyasu's shrine in 1637: "The Three Ambassadors paid their respects... solely because the three generations of peace [between Japan and Korea] and the peace of Korea are due entirely to the high grace of Tōshōgū" (Toby, 1991: 99). The missions were hosted at the expense of the shogunate, a practice which mirrored the Chinese custom of paying for the expenses of the foreign emissaries.

\subsection{Red-haired Barbarians and the Japanese Centre}

What role, then, did the "red-haired barbarians" - as the Europeans were called - play in Japan's international relations during this time? While relations between the Europeans and the Japanese were primarily based on trade, the Europeans were nevertheless incorporated into the Japan-centric East Asian international order by interacting on the terms dictated by the Japanese. As far as Japan's feudal rulers were concerned, the Europeans could become useful tools by which to demonstrate the wide-spread nature of their prestige as righteous rulers and consolidate their legitimacy to rule.

In accordance with the principle of hierarchical sovereignty, European states that interacted with members of the East Asian international order had to be assigned a place within the social/civilisational hierarchy. This was common practice for other states in East Asia, most famously China. Europeans who wished to cultivate some form of relations - trading or political - with the Chinese empire had to conform with these norms, as famously demonstrated by Lord Macartney's mission to China in 1793. In the case of Japan, such practices can also be seen as early as 1591, when Toyotomi Hideyoshi, the feudal ruler of Japan between 1590-1598, ordered the Portuguese Governor General of India and the Spanish rulers of the Philippines to present tribute. The Tokugawa shogunate was no different. As was with the Chinese world order, "[t]he Tokugawa regime created for itself a naturalized version of the sinocentric world order of a civilized core surrounded by barbarian or at best imperfectly civilized peripheries" (Howell, 1998: 119). Japan was thus placed within the Chinese cultural world (albeit at the apex), which the Japanese astronomer Nishikawa Jokenlabelledgaikoku in his 1708 work, Kai $t s \bar{u} s \bar{o} k \bar{o}$. The Dutch were placed within the sphere of the gaii, or "outer barbarians".

It is worth mentioning, however, that the Japanese - in contrast to their Chinese and European counterparts neither entirely saw civilization as "progress in relation to the political, economic, and social institutions and practices of a society" nor as "a single and universal concept used to describe a teleological process through which individuals and groups became civilized" (Hirono, 2008: 22). Whereas the Chinese (who shared broadly similar culturalist views of the non-Chinese world with the Japanese) tended to hold that Chinese civilization was inherently superior and that the Chinese emperor could guide the "barbarians" to progress, the Japanese came closer to what Miwa Hirono (2008: 22) calls a "pluralist conception of "civilizations"” (Note 4), and viewed these three worlds as "self-governing worlds with their own states, societies and cultures" (Arano, 1998: 53). This divergence, Arano Yasunori(1998: 53) notes, possibly originated from the fact that "the Japanese state authorities had no choice but to construct their self identity under the political and cultural influence of China, 
India or Korea." Nevertheless, the norms of the East Asian international order were a "heavy chain that bound the inner and outer worlds of the early modern Japanese" (Arano, 1998: 61) and the Tokugawa shogunate did insist that appropriate social rituals governing diplomatic conduct were observed by the "outer barbarians". As Tashiro Kazui (1982: 289) notes, "in [Japan's] dealings with the Ryukyus and Holland, which can hardly be described as normal diplomatic relations between countries of equal standing, Japan insisted that it be paid a sort of tributary mission" for this benevolent act of kindness by the ruler, even though official diplomatic relations did not exist.

This of course does not imply that the norms governing "ritual justice" in the Japan-centric Tribute System had already been established by the Tokugawa shogunate when it began interacting with the Europeans. The Dutch, who by the mid-seventeenth century were the only Europeans permitted to interact with the Japanese rulers, were invited to display their gifts in front of the Japanese ruler, who would acknowledge their "tribute" with a silent nod. A Dutch emissary to China 1667 was granted an audience with the Kangxi emperor in a style which also mirrored that of Japan, making this "style of audience a uniquely East Asian one" (Nagazumi, 1990: 99). Nevertheless, the Tokugawa shogunate did face the same problem that the Europeans encountered later when non-European peoples were incorporated (often against their will) into the European international order in the age of imperialism. Indeed, at times ritual protocol was not always observed by the Japanese rulers, especially when the shōgun himself was either personally favorably disposed towards the Europeans or had specific desires for trading relations (Note 5). The East Asian international order, however, "did not exist by itself; rather, it had to be reconfirmed in the arena of external relations" (Arano, 1988: x). As the Tokugawa shogunate sought to consolidate and legitimate its rule both to its domestic and international audiences, it soon began to formalize the institutional arrangements surrounding Japan's interactions with the "outer barbarians" and differentiate them from those who came from the East Asian cultural sphere. In this sense, the Europeans would serve as an important "Other" that would function to highlight Japan's own identity as a "civilized" and paternalistically "benevolent" head of the East Asian international order.

Consequently, the Netherlands continued to play a crucial role in the construction of Japan's own "Tribute System" until the expansion of European International Society into East Asia. The Dutch served to confirm their "outsider"/"outer barbarian" status in the Japan-centric Tribute System. They were required to pay a visit to the shōgun in Edo (present day Tokyo), and this occasion served a similar function to Tribute missions by the Koreans and Ryūkyūans, reinforcing the social structures of the East Asian international order (albeit with Japan as the centre, rather than China). Strict, hierarchical "diplomatic" protocols governed the etiquette of the Dutch visit. The shoggun did not "receive" the delegation as he did for the Koreans or the Ryūkyūan emissaries; rather, "the shogun was recorded... as 'viewing' the Hollanders, much as he had 'viewed' entertainments offered by the Korean equestrian troop or the Ryūkyūan musicians" (Toby, 1991: 190). The Dutch were not allowed to speak to the shogun, and neither were they allowed to present him with any petitions. The differential treatment given to the Dutch by the Japanese (in contrast to their reception of the Korean or Ryūkyūan missions) mirrored the Canton system of trade adopted by Qing China, where "outer barbarians" were segregated from the local populace and allowed limited trade as an "imperial favor".

The Dutch were well aware of their position within the Japan-centric Tribute system, and employees of the Dutch East India Company resident in Nagasaki were instructed to be "armed with modesty, humility, politeness and friendship, always behaving as inferiors" (Boxer, 1984: 539). In a fascinating account that demonstrates how Tokugawa diplomatic symbols had evolved since the time of Tokugawa Ieyasu, Engelbert Kaempfer, the German physician to the Dutch delegation, recorded that in the audience with the shogun, the Dutch trade representative greeted the Japanese rulers as follows: "kneeling, he [the Dutch trade representative] bow'd his forehead quite down to the ground, and so crawl'd backwards like a crab, without uttering one single word. So mean and short a thing is the audience we have of this mighty Monarch" (Toby, 1991: 193). The Dutch were even prepared to play the fool in their audience with the shoggun if necessary. Kaempfer reported that "[t]here was a Royal Viewing (jöran) of the four Hollanders" at which the Europeans were required, "to walk, to stand still, to compliment each other, to dance, to jump, to play the drunkard, to speak broken Japanese, to read Dutch, to paint, to sing, to put our cloaks on and off...In this manner, and with innumberable such other apish tricks, we must suffer ourselves to contribute to the Emperor's and the Court's diversion"" (Toby, 1991: 194).

All of this was possible because the Europeans were unable to force the Tokugawa shogunate to accept and participate in European norms of interstate interaction (Massarella, 2001: 26) (Note 6). As far as the Dutch were concerned, their priorities lay in establishing themselves as trading partners of the Japanese. In the early-seventeenth century, the Netherlands was still competing with the Portuguese for the shogun's trading privileges (their other rivals, the English, had closed down their trading house in Hirado in 1623, following poor 
profits). Given the shogunate's suspicion of the Portuguese Jesuits, the Dutch were well aware that if they refrained from proselytizing in Japan, they had the chance to monopolize Europe's trade with Japan - and they eventually succeeded in this endeavor in 1639, when the Portuguese were banned from sailing to Japan. After this date, it made even less sense (at least from the point of view of trade) for the Dutch to get entangled in disputes with the Tokugawa shogunate over diplomatic rituals.

In light of these considerations, the Dutch were effectively willing to incorporate themselves into the East Asian international order for the sake of maintaining harmonious trading relations, and it is important to note that this arrangement lasted for more than 200 years. They shied away from confronting Japanese officials over diplomatic protocol by simply not sending any ambassadors or letters from the Dutch sovereign (Nagazumi, 1990: 125). Instead, they limited their interactions with Japan on a "commercial" basis, with any diplomatic interactions taking place between the Dutch head of the trading house and appropriate officials of the Tokugawa shogunate.

\section{3. "Civilized" Europe and Japan at the Periphery}

Japan's ethno-centric views of Europe came tumbling down in 1853, when Commodore Perry of the US navy appeared on Japan's shores, effectively kicking open Japan's "closed" doors to the expanding European order. While the desire to find markets for European goods was a significant part in Europe's drive to force Japan to engage with Europe, another key motivation was the renewed confidence in European "civilization" and a belief that Europe had a unique mission to spread its benefits (Adas, 1990). A related development was the gradual labeling of non-European polities and peoples as "savage" or "barbarous". International law at that time reflected this line of thinking, and treated "uncivilized" polities as beyond the pale; accordingly, these states were not accorded the full protection of international law, let alone equal treatment with the "civilized" European powers (Gong, 1984). The only pathway to attaining equality with the Europeans was fulfilling the "standard of civilization" and remodelling the state along European lines.

It did not take long for the Japanese to learn that they were given differential treatment via-a-vis the Europeans. The Tokugawa shogunate was compelled to enter into a series of unequal treaties which symbolized Japan's "uncivilized" status. As the Japanese began to learn more about European international relations and visit Europe themselves, they came to the realization that intra-European relations (or, international relations among the "civilized" states) were characterized by equality, where each states' sovereignty was respected (Suzuki, Shogo, 2009). In contrast, those who were deemed "uncivilized" were often placed under European colonial rule, or subjected to the same unequal treaties that symbolized their lowly social standing in the eyes of the European powers. Consequently, the Japanese realized that the "standard of civilization" served to differentiate between "barbarous" and "civilized" entities, and that they would have no choice but become a "Westernized" state if they were to rid themselves of this stigma and prevent any possible European encroachments on their land.

This process was provided with much-needed momentum by the Meiji leadership which seized power from the Tokugawa rulers in 1867. Many of the Meiji leaders had experience of travelling abroad, and their first-hand experience of seeing European industrialization and military power led them to gradually absorb the universalistic notion that the only way (for Japan, as well as other polities) to attain "civilized" status was to adopt European political institutions, industry, and military technology. Accordingly, the new national goal became datsua nyūō (leave Asia, join Europe). Europe therefore was seen as a crucial model for Japan to emulate, and the Meiji government demonstrated this by sending a study group, the famous Iwakura mission, which set off on a tour of Europe and the US in 1871. Japanese state's institutions were remodelled on European lines, while the leaders and public alike adopted Western-styled clothing and haircuts. Realizing that the "civilized" European powers also appointed themselves to the role of "teaching" "savage" entities the trappings of "civilization", often through colonial tutelage, the Japanese were also quick to engage in "mimetic imperialism" and acquire their very own empire, beginning with the annexation of Taiwan in 1895 after the Sino-Japanese war. If Europe was Japan's "positive Other" that was a source of emulation, Asia became Japan's "uncivilized Other" that would serve to highlight Japan's similarity with Europe. Furthermore, by "teaching" their "uncivilized" Asian neighbors the "civilized" way of life, Japan could also bring to attention its own civilizational attainment. This line of thinking can be seen in Takekoshi Yosaburō's (1907/1996: vii) preface in his Japanese Rule in Formosa, where he wrote: "Western nations have long believed that on their shoulders alone rested the responsibility of colonizing the yet unopened portions of the globe, and extending to the inhabitants the benefits of civilisation; but now we Japanese, rising from the ocean in the extreme Orient, wish as a nation to take part in this great and glorious work".

The drive to attain "civilized" status on European terms was, however, not always an uncritical one. While there 
is no reason to doubt that genuine appreciation for European "civilization" provided the impetus to reinvent Japan along Western lines, it is important to note that Japan also had very little choice but to "Westernize". Refusal to do so would mean that Japan suffer a similar fate to its immediate neighbor, China (which, alongside Turkey, was often used as a "negative example"), that had suffered multiple military defeats at the hands of the Europeans and subsequently lost many pockets of her territory and become a "semi-colonized" state. Given that Japan's process of state reconfiguration was partly carried out under duress, it is not particularly surprising that many Japanese were resentful and uncomfortable with the blatant racism that undergirded the "standard of civilization", as well as the sudden political and social changes it compelled Japan to undertake. In this sense, Europe was a Janus-faced entity that was viewed simultaneously with admiration and fear.

Such views reflected Japan's long-standing suspicion towards the European-dominated international environment, and these sentiments of disquiet seemed to be fully justified in 1919, when the League of Nations failed to adopt a clause on racial equality. To many Japanese, Japan could never attain the same identity with Europe, no matter how hard they tried. The Asia-Pacific War (1931-1945), which broke out two decades later, was in part related to Japan's deep-seated dissatisfaction with its own status within European International Society. It is crucial to note that Japanese aggression during this time was justified under the rhetoric of constructing a new international order that was free from European racism and domination. The fact that this propaganda enjoyed considerable social resonance at the time attests to the deep-seated negative image of Europe as a threatening, racist, entity that was held by many Japanese. Yet, Japanese imperialism also showed signs of "mimicry", where an actor appropriates some aspects of an "Other's" visions of power, thus blurring the boundaries between "self" and "other", "Asia" and "Europe" (Bilgin 2008: 14) (Note 7). Despite the call for Asian brotherhood and a sharp rhetorical denouncing of European imperialism, Japan's leadership role in this "non-Western" "non-racial: alternative international order was hardly questioned. This meant, in effect, that Japan continued to play the role of a paternal, but benevolent entity whose role was to guide the non-European states to true freedom and happiness (albeit outside the European yoke). Japan thus retained its connections and identification with Europe, in that saw itself as inherently different and superior to the rest of Asia.

\section{Europe in Japan under US Hegemony}

Japan's utter defeat in the Asia-Pacific War in 1945 and its subsequent incorporation into the pax Americana system, coupled with the decline of European political and economic power, has meant that Europe as an independent entity has featured less in Japanese international politics compared to the pre-war era. As noted above, the US almost single-handedly reconstructed Japan's economy and played a large role in its rebirth as a democracy. Because of America's status as a Pacific power and a superpower, it is perhaps unsurprising that "many Japanese have looked to the US as their window on the world, and they have studies in American universities; so many business and investment links have been forged across the Pacific that the Europeans have not been able to compete" (Nuttall, 1996: 104). Except for trading disputes, political relations with Europe hardly seem to feature on Japan's radar. The government's official exposition of its EU policy is filled with bland statements of strong desires to continue dialogue and cooperation (Ministry of Foreign Affairs, 2010: 24). The low political profile of Europe in popular opinion can also be seen in the Cabinet Office's regular surveys of foreign policy. While citizens' views on the US, Russia, China, and South Korea have been sought every year between 2000-2009, this is not the case for Europe. Furthermore, the surveys taken between 2000-2006 showed that a higher percentage of those polled "felt a sense of closeness (shitashimi o kanjiru)" to the US than Western Europe and the EU, as Chart 1 shows (Cabinet Office, Japan, 2008).

\subsection{Europe as a Marker for "Civilized" Identity?}

Nevertheless, this does not necessarily mean that Europe has simply dropped off the map and ceased to "matter" for the Japanese. While Japan's revolt against European world order during the Asia-Pacific War was partly (as noted above) directed towards the latent racism and inequality that many European states still held vis-à-vis Asians and Africans, it is important to note that Japan's loudly trumpeted call for unity and equality among the non-white races often remained at the level of rhetoric. As Kurosawa Fumitaka notes, Japan's vision for a new world order, the Great East Asian Co-Prosperity Sphere, was "a hierarchical structure" which "did not recognize Western concepts of sovereignty and equality" (Kurosawa, 2004: 10). Furthermore, Japan's leading position and right to "survival and self-defense" was to be respected above all other Asian states (Kurosawa, 2004: 11). While this is not to deny the existence of other domestic discourses within Japan that genuinely sought racial equality, such policies certainly do demonstrate the lingering influences of Japanese exceptionalism among the policy elite, which regarded other non-European states as decidedly inferior and never quite identified Japan as an integral part of Asia. 
Such ideology arguably continued to exert considerable influence within post-World War II political circles in Japan (Note 8), particularly in the sense of identifying Japan as part of the "Western camp (nishigawa jin'ei)" or the "Free world (jiy ü jin'ei)", if not the "Occident (seiyō)", as in the Meiji period. Consequently, "the preservation of domestic peace and democracy, with its 'respect for personal freedom and human rights,' became an integral and inseparable part of Japan's path of 'peace and prosperity' within the camp of 'free nations"', particularly among the conservative elites who continued to hold power (Bukh, 2010:38) (Note 9). In this context, (Western) Europe, as members of the Western camp, became an important "positive Other" that Japan could aspire to as it sought to carve out an identity for itself as part of the "Free World".

Thus, seeking (perceived symbolic) equality with European states became a pressing diplomatic goal for the Japanese government after 1945. A case in point can be found in the 1960s, when Japan was denied both access to European markets (under Article 35 of the General Agreement on Tariff s and Trade) entry into the Organisation for Economic Co-operation and Development (OECD) because of European opposition. Altering this situation would naturally improve the scope for the fast-growing Japanese businesses to find overseas markets, but was understood as having important "political value" because "the abolition of economic discrimination in Europe and [European] recognition of Japan's entry into the OECD would indicate the improvement of Japan's international status" (Suzuki Hironao 2008: 97). The then Prime Minister Ikeda Hayato considered the organization to be a "salon of advanced countries" and became "obsessed about [membership of the OECD] because Japan would be treated as a second-rate power [nitōkoku atsukai] if it did not join" (Suzuki, Hironao, 2005: 60). It is significant to see the social value attached to the OECD as an identity marker to bestow prestige on Japan. Given that most of "Western Europe, the US and Canada were already members of the organization at the time" (Suzuki, Hironao, 2005: 59), Ikeda's behavior strongly suggests that membership in social groupings that included (Western) Europe were seen as "desirable", and something that Japan should aspire to. Furthermore, insofar as an actor's identity is confirmed through social interaction and recognition by others, Europe was also perceived as an important social actor that could bestow positive affirmation that Japan was "one of them", ultimately by granting Japan's application to join the OECD in 1964.

\section{Conclusion}

In today's context, official statements on EU-Japan relations that state the two actors are "global partners that share fundamental values" (Ministry of Foreign Affairs, Japan, 2010: 24) serve to remind us that the EU still has symbolic power as an important identity marker for Japan, despite the limited political interactions Europe has in comparison to the US. It holds a broadly favorable image, with an average of $56.7 \%$ of Japanese polled holding positive images of the region between the years 2000-2006. This was significantly higher than China (42\%) and marginally higher than South Korea (52.5\%) (Cabinet Office, Japan, 2001-2006). This, however, does not necessarily mean that the EU is seen as an advanced, post-Westphalian form of International Society, as is often the case in Eurocentric perspectives often found in European policy-makers and scholars (cf Buzan and Little, 2000). Part of this reason is of course the awareness among Japanese EU scholars of the various democratic deficits within EU governance (Asami, 2008).

But perhaps most salient is the simple political fact that the East Asia region has not been able to overcome the mutual antipathy that has dogged their relations. Japan's handling of its negative historical legacy has not met the satisfaction of its neighbors. As a result, there is a lingering image of Japan as a latent threat (Lind, 2008). This hinders any political integration and renders Europe's experience meaningless in East Asia, and hinders any aspirations towards realizing an EU-style model of governance in East Asia. In this sense, then, there is both continuity and change in Japan's image of Europe: the favorable image of Europe (and the US), coupled with fact that Europe has remained a significant "reference group" for Japan means that there arguably remains a latent (but significant) strand of "leave Asia, join Europe" thinking within Japan, thus placing Japan's "Asian" credentials into doubt once more. This is not, however, a uniquely "Japanese" phenomenon, however: it should be noted that a highly essentialized and idealized "West" (which includes Europe) has been constructed within Chinese counter-discourses as a means of criticizing the illiberal governance of the communist regime in Beijing (Chen 1992). Nevertheless, the importance that Europe holds within such Japanese discourses has - inevitably, perhaps - waned in the age of Pax Americana, where the U.S., with its sense of exceptionalism and eagerness to propagate American values as a universal ideal and aspiration, has made its normative and material power felt throughout the world.

One relatively new development in the region that has the potential to change this dynamic is of course the recent rise of China. In an attempt to reassure its neighbors that its growing political, military and economic power is not a threat, Beijing has recently launched a "soft power" offensive that is aimed to increase its attraction and facilitate the acceptance of its rise, and some authors have claimed that the Chinese have been 
remarkably successful in this endeavor (Kurlantzick, 2007). Furthermore, some scholars have even suggested that China's rise to the status of a regional hegemon is actually a return to historical normalcy, and that it is likely that many Asian states will accept a hierarchical international order with China at the apex (Kang, 2007). With its (allegedly) growing charm, will China become Japan's "positive Other", and entice the Japanese to reconsider their position as members of the "West", including the US and Europe? There are a number of reasons to think not. First, as mentioned above, the "history problem" continues to fester between China and Japan. Second, the political systems between Japan and China are simply too different to achieve any meaningful political integration. China remains an authoritarian, one-party state, and the image of its political system suffered badly in the eyes of the Japanese public when it brutally suppressed the demonstrations on Tiananmen Square in 1989. Many post-communist states in Eastern Europe were required to democratize along Western European models to join the EU, and the EU was in a position of strength to enforce this demand. Japan has no power whatsoever to impose its vision of desirable domestic governance on Beijing, and this means that an "EU in East Asia" will have to wait until the day China democratizes.

In sum, it is still arguable that Europe and the EU still retain a substantial role in shaping Japan's own identity, albeit under the broader social grouping of the "West", led by the United States. In this sense, Europe remains an important "Other", but its significance has substantially been reduced under American hegemony and the subsequent weakening of European political relations with Japan. Writing in 1996, Simon Nuttall (1996: 116-119) argued that both sides needed to expand the "range of dialogue" and increase "the frequency of encounters", and deepen mutual understanding "at the popular level". Investigating whether or not the EU and Europe chooses to do so is beyond the remit of this essay - but with increasing inroads made by Japanese popular culture in Europe in recent years, coupled with the continued existence of Europe as Japan's "positive Other", the Europeans are well-placed to fulfilling this political goal should they wish to do so.

\section{References}

Abizadeh, A. (2005). Does Collective Identity Presuppose an Other? On the Alleged Incoherence of Global Solidarity. American Political Science Review, 99(1), 45-60. http://dx.doi.org/10.1017/S0003055405051488

Adas, M. (1990). Machines and the Measure of Men: Science, Technology, and the Ideologies of Western Dominance. Ithaca: Cornell University Press.

Arano, Y. (1988). Kinsei Nippon to higashiajia. Tokyo: Tōkyō daigaku shuppankai.

Asami, M. (2008). Ōshūrengō wa minshutekika?. Keiō hōgaku, 3, 299-325.

Bilgin, P. (2008). Thinking past "Western” IR?. Third World Quarterly, 29(1), 5-23.

Boxer, C. R. (1984) When the Twain First Met: European Conceptions and Misconceptions of Japan, Sixteenth-Eighteenth Centuries, Modern Asian Studies, 18(4), 531-540. http://dx.doi.org/10.1017/S0026749X00016267

Bretherton, C., \& Volger, J. (1999). The European Union as a Global Actor. London: Routledge. http://dx.doi.org/10.4324/9780203196076

Bukh, A. (2010). Japan's National Identity and Foreign Policy: Russia as Japan's “Other”. London: Routledge.

Buzan, B., \& Little, R. (2000). International systems in World History: Remaking the Study of International Relations. Oxford: Oxford University Press.

Cabinet Office, Japan. (1975-2010). Gaikō ni kansuru yoron chōsa. Retrieved November 1, 2010, from http://www8.cao.go.jp/survey/index-gai.html

Chen, X. (1992). Occidentalism as Counterdiscourse: "He Shang" in Post-Mao China. Critical Inquiry, 18(4), 686-712. http://dx.doi.org/10.1086/448652

Drifte, R. (2000). Japan and the European Union.In I. Takashi, \& P. Jain (Eds.), Japanese Foreign Policy Today (pp. 194-208). Basingstoke: Palgrave.

Fairbank, J. K. (1968). The Chinese World Order. Cambridge, Massachusetts: Harvard University Press.

Gong, G. W. (1984). The Standard of "Civilization" in International Society. Oxford: Clarendon Press.

Hirono, M. (2008). Civilizing Missions: International Religious Agencies in China. New York: Palgrave Macmillan.

Howell, D. L. (1998). Territoriality and Collective Identity in Tokugawa Japan. Daedalus, 127(3), 105-132. 
Huntington, S. P. (1996). The Clash of Civilizations and the Remaking of World Order. New York: Simon and Schuster.

Ikenberry, G. J. (2000). After Victory: Institutions, Strategic Restraint, and the Rebuilding of Order after Major Wars. Princeton: Princeton University Press.

Kang, D. C. (2007). The Rise of China. New York: Columbia University Press.

Kurlantzick, J. (2007). Charm Offensive: How China's Soft Power is Transforming the World. New Haven: Yale University Press.

Kurosawa, F. (2004). Joron: nippon gaikō no kōsōryoku to aidentitii. Kokusai Seiji, 139, 1-12.

Lind, J. (2008). Sorry States: Apologies in International Politics. Ithaca: Cornell University Press.

Mancall, M. (1984). China at the Centre: 300 Years of Foreign Policy. New York: The Free Press.

Massarella, D. (2001). "Ticklish Points": The English East India Company and Japan, 1621. Journal of the Royal Asiatic Society, 11(1), 43-50.

Ministry of Foreign Affairs, Japan. (2010). EU jijō to nichi-EU kankei. Retrieved November 10, 2010, from http://www.mofa.go.jp/mofaj/area/eu/pdfs/jijyou_kankei.pdf

Nagazumi, Y. (1990). Kinsei shoki no gaikō. Tokyo: Sōbunsha.

Neumann, I. B. (1999). Uses of the Other: "The East" in European Identity Formation. Minneapolis: University of Minnesota Press.

Nuttall, S. (1996). Japan and the European Union: Reluctant Partners, Survival, 38(2), 104-120. http://dx.doi.org/10.1080/00396339608442848

Reus-Smit, C. (1999). The Moral Purpose of the State: Culture, Social Identity, and Institutional Rationality in International Relations. Princeton: Princeton University Press.

Rumelili, B. (2004). Constructing Identity and Relating to Difference: Understanding the EU's Mode of Differentiation. Review of international Studies, 30(1), 27-47.

Suzuki, H. (2005). OECD kamei no gaikō katei: "seiji keizai ittai” rosen to shite no jiyū jinei ni okeru gaikōteki chihei no kakudai. Kokusai seiji, 140, 57-72.

Suzuki, H. (2008). Ikeda gaikō no kōzu: tai “jiyū jin'ei” gaikō ni miru naisei to gaikō no renkan. Kokusai seiji, $151,89-104$.

Suzuki, S. (2009). Civilization and Empire: China and Japan's Encounters with European International Society. London: Routledge.

Takekoshi, Y. (1996). Japanese Rule in Formosa. Taipei: SMC Publishing. (Reprinted from Longmans, Green and Co. (London), 1907.)

Tanaka, T. (1975). Chūsei taigai kankei shi. Tokyo: Tōkyō daigaku shuppankai.

Tashiro, K. (1982). Foreign Relations during the Edo Period: Sakoku Reexamined. Journal of Japanese Studies, $8(2), 283-306$

Toby, R. P. (1991). State and Diplomacy in Early Modern Japan: Asia in the Development of the Tokugawa Bakufu. Stanford: Stanford University Press.

Tsukamoto, M. (1979). Edo jidai ni okeru “i” kannen ni tsuite. Nihon rekishi, 37(1), 1-18.

Zhang, Y. (2001). System, empire and state in Chinese international relations. Review of International Studies, 27(Special issue), 43-63.

\section{Notes}

Note 1. This aspect of Japan-Europe relations has surprisingly been missed in the field of International Relations. While a full explanation of why this is the case is beyond the scope of this article, one possibility is the pernicious influence of Eurocentrism in the discipline, which has tended to explore the European international order as "the only game in town", and worth of serious academic attention. Thus, there is a tendency to only study interactions between European and non-European polities from the vantage point of European/Western strength, where non-Europeans have been assimilated (often against their wishes) into the normative structures of the European international system. Previous interactions where non-European polities interacted with the West on their own terms is simply bracketed out from the narrative of "international history". 
Note 2. The policy adopted by China, for example, consisted of the state banning its peoples from private overseas travel and trade. It was first implemented by the Ming dynasty of China to prevent 'Japanese' piracy (known as wakō or wokou) and monopolize trade. Note, however, that Japanese only constituted about 10-20 percent of the "Japanese" pirates.

Note 3. It should be noted, however, that Japan was not exactly alone in its resistance towards Sinocentrism: states such as Korea and Vietnam defied Chinese claims of superiority at various points in their history at various times. This, of course, has interesting implications for recent culturalist arguments that claim an Asian tendency to accept hierarchical international relations.

Note 4. According to this view, civilisations are seen as "distinct cultural entities, and therefore... used to define and differentiate the characteristics of societies." One of the more contemporary expressions of this view is of course Huntington 1996.

Note 5. The first shōgun Tokugawa Ieyasu was particularly known for his openness towards Europeans, even appointing a William Adams, a Briton, as his advisor. A delegation from the Netherlands (1611) and the former Spanish governor of the Philippines (1609) were both spoken to by Tokugawa Ieyasu during their respective audiences with the shogun. Nagazumi (1990: 100-101) states that this was possible because of the Adams' personal introduction of the Dutch, as well as the shogun's own desire for trade with Spain.

Note 6. This was the case for the English as well. The attack on Chinese, Portugues and Spanish ships by the joint fleet of English and Dutch East India Companies in 1621 near Japanese waters incurred the displeasure of the Tokugawa shogunate, who imposed further restrictions on English and Dutch trading privileges. John Osterwick, based at the English trading house in Hirado, wrote at the time that 'the pres[en]t estate of this Countrie, towching our selfe\& the Hollanders, you may please to vnderstand that wee stand vppon ticklish points of loosing our priviledges \& to be put out of the Countrie.' This again is indicative that the Europeans were in no position whatsoever to dictate the terms of how they interacted with the Japanese.

Note 7. Bilgin's insights draw heavily on Homi K. Bhabha's concept of "hybridity".

Note 8. While I do not wish to suggest an almost seamless continuity in diplomatic thinking between pre-war and post war Japan, this point can be justified by the fact that many of the pre-war political elites who were initially purged by the Allies were eventually rehabilitated as part of American Cold-War strategy of integrating Japan into the Western camp. Many of the Japanese pre-war elite held anti-communist views, and were perceived as capable of playing an important in preventing the spread of communist influence in Japan.

Note 9. It should be noted, however, that the Japanese political left had similar aspirations of Japan as a "democratic" state that was "peaceful" and "prosperous". In the context of the Cold War, they departed from the conservative mainstream in their advocating Japan's abandonment of the US-Japan Security Alliance and thus pursuing a more politically neutral stance, thus avoiding unnecessary involvement in the standoff between the capitalist and communist camps under bipolarity. 